\title{
On Value and Obligation in Practical Reason: Toward a Resolution of the Is-Ought Problem in the Thomistic Moral Tradition
}

\author{
William Matthew Diem \\ Gettysburg, PA
}

"This brings us to one of the most pointless controversies of modern moral philosophy, ... How can we move from the descriptive to the normative, from fact to value, from Is to Ought?"1

\section{Introduction}

HumE'S IS-ought ${ }^{2}$ gap is, in the Thomistic moral tradition, regularly treated as being the same problem as the fact-value gap. The transition between the two is routinely just as swift and little-noted as that which the Scot observed from "is" to "ought" in the ethical discourse of his own day. ${ }^{3}$

1 Ralph McInerny, Ethica Thomistica, rev. ed. (Washington, DC: Catholic University of America Press, 1997), 37.

2 David Hume, A Discourse of Human Nature (Oxford: Clarendon Press, 1888), III, pt.1, no. 1: "In every system of morality, which I have hitherto met with, . . the author proceeds for some time in the ordinary way of reasoning, and establishes the being of a God, or makes observations concerning human affairs; when of a sudden I am surpriz'd to find, that instead of the usual copulations of propositions, $i s$, and is not, I meet with no proposition that is not connected with an ought, or an ought not. This change is imperceptible; but is, however, of the last consequence. For as this ought, or ought not, expresses some new relation or affirmation, 'tis necessary that . . . a reason should be given ... how this new relation can be a deduction from others, which are entirely different from it" (469).

3 This identification of the two problems is quite understandable insofar as awareness of the fact-value gap is generally traced to G. E. Moore's attack on ethical naturalism in his Principia Ethica (Cambridge: Cambridge University Press, 1903), where he himself used his "open question" to challenge the intelligibility of evaluative statements in general, including normative statements; i.e., his challenge concerning evaluative statements includes the specific sort of moral value that is equivalent to "ought." 
Further, these two dichotomies (fact-value and is-ought) are regularly treated as being identical, not only to one another, but also to Aristotle and Aquinas's distinction between practical and speculative. ${ }^{4}$ And the question whether (and if so, how) practical ("ought" or normative) knowledge is derived from speculative ("is" or descriptive) knowledge has driven some of the fiercest disputes among the schools of Thomistic theorists of natural law.

I intend to show that both of these identifications are wrong and the debate has been misframed. The is-ought gap is not the fact-value gap, and neither of them corresponds neatly to Aquinas's distinction between the speculative and practical. Conflating value and obligation has resulted in an insoluble problem, but if, as I intend to show, they are both distinct in themselves and treated as such by Aquinas, then the possibility opens of a resolution-within the Thomistic school—to a debate that has, heretofore, proven particularly resistant to consensus.

My treatment will proceed in four sections. I intend first to explain and defend the thesis that there is a fact-value gap: the bare understanding of speculative truth does not move an agent to act unless it first touches a desire or natural inclination. I will show that Aquinas is well aware of this gap and respects the distinction between purely factual knowledge and value in his moral psychology. Second, I intend to show that value and

4 For example, McInerny, Ethica Thomistica, 37, quoted as the epigraph of the present essay; see also 48-50. Steven A. Long, The Teleological Grammar of the Moral Act, 2nd ed. (Naples, FL: Sapientia Press, 2015), 72-76, provides a brilliant example. He begins speaking of Hume and the is-ought problem, swiftly moves to a discussion of speculative knowledge of teleology and its relation to practical knowledge and desire, then speaks of the divide between "fact" and "value," before returning to the relation between "ought" and "is," all of this without any indication that these are distinct questions. See also John Finnis, Natural Law and Natural Rights (Oxford: Clarendon, 1980), 37 ("Aquinas's Aristotelian distinction between 'speculative' and practical reason corresponds so neatly with the modern ... distinction which we . . . indicate by contrasting 'fact' and 'norm' or 'is' and 'ought'”), and in his subsequent treatment of Clarke (whom he contends Hume was originally critiquing in his famous no-is-from-ought passage), he conflates obligation with value or desire: "Clarke's argument fails to make the transition from is ... to ought because it fails to advert to any desire or interest of the agent's that might be satisfied by acting rightly. . . . It fails to consider whether acting fittingly and reasonably is in any aspect of ... the agent's well-being or in any way worth while or desirable" (40-41). See also Steven Jensen, Knowing the Natural Law: From Precepts and Inclination to Deriving Oughts, (Washington, DC: Catholic University of America Press, 2015), 1-2: "[David Hume] suggested that it is illegitimate to begin with a statement of fact about the way the world is and to conclude with a value, of what is good or of what should be." 
obligation are distinct concepts and therefore the fact-value gap is not the is-ought gap, although-as I will also show-the two are routinely conflated in the contemporary Thomistic dispute over the relation of speculative to practical knowledge. In the third section, I intend to show that Aquinas clearly distinguishes between obligation and value, and in fact, he recognizes two clearly discrete forms of practical reason that answer to these two discrete notions, with each form of practical reason having its own distinct set of principles. Finally, I intend to show in the fourth section that, while conflating value and obligation led to an insoluble problem, conversely, once the notions of value and obligation are clearly distinguished, the is-ought gap poses no particular difficulty and the principal concerns of both sides in the debate can be answered. With these clarifications made, I will suggest a detailed, if tentative, account of precisely how synderesis gives us our first awareness of moral law from a prior speculative understanding.

\section{That There is a Fact-Value Gap}

By "value" I mean to name such desire or care for a thing as is necessary for that thing to motivate deliberate activity. Value-considered as that which is psychologically sufficient to serve as a motive for action-is, at root, a function of appetite or inclination: to value something is to desire it.

Since "good" denotes the desirable, it is natural to use the language of goodness when discussing value, but because "good" is an analogous term, there is here a danger of confusion and equivocation, and as will become apparent, it is precisely averting such confusion that makes a discussion of the fact-value gap necessary. I readily admit that there are speculative or purely descriptive senses of "good" which are founded on our apprehension of a thing's teleology. A thing can be called good in itself, for example, if it is complete in its kind and fulfills its purpose or acts in a way conducive to its natural end; thus we might speak of a spider as good if it is healthy and demonstrates the characteristics and behaviors that are typical of its species. Similarly, one thing can be called good for another if it conduces or contributes to the other's attaining its telos-thus we might say that it is good for the spider to eat the fly. Nonetheless, I insist, such speculative apprehensions of goodness, rooted in an understanding of teleology, cannot, of themselves, provide a motive for deliberate action and so do not constitute value in the relevant sense. To extend Alisdair MacIntyre's example from After Virtue, ${ }^{5}$ knowing that a watch is a good watch, that it

5 Alasdair MacIntyre, After Virtue, 2nd ed. (Notre Dame, IN: University of Notre Dame Press, 1984), 57-58. See also Peter Geach, "Good and Evil," Analysis 17 
has what a watch ought to have given its purpose (it is portable, keeps time accurately, and is stylish), does not motivate me unless I already want or desire a watch in some respect (perhaps desiring to amend my chronically tardy life, or desiring to signal my flawless taste to my peers). Likewise, just knowing that it is good for the spider to eat the fly does not, of itself, give me a reason to care whether the spider actually gets the fly, nor does the bare knowledge that this spider is an ideal specimen of its species provide me a motive for any particular action. In a similar way, a speculative account of human nature, including what makes a human a good human, does not move me to act unless I somehow desire to be a "good human," and a speculative account of what constitute good human acts cannot motivate me to perform such acts unless I already desire to perform good human acts as such, that is, unless I desire to be virtuous. As Peter Geach himself readily concedes, "it ought to be clear that calling a thing a good A does not influence choice unless the one who is choosing happens to want an A." Knowledge must touch desire before it can give rise to act, for an apprehension moves only through an appetite.

If my apprehension of some thing is to move me to act, I must experience a desire for that sort of thing. I must care about that sort of thing. Marshal whatever facts you like, but until those facts touch on a desire that I experience, those facts will not constitute, for me, a motive for action. Hence the sort of apprehension of good that moves an agent to act is not a purely speculative apprehension of good, but the good insofar as it actually corresponds to a value of the one it motivates and insofar as it thus touches a prior desire.

This first distinction maps directly to a second fundamental distinction: namely, between an observed desire and an experienced desire. ${ }^{7}$ I

(1956): 33-42, for an early use of descriptive good as a defense against ethical non-naturalism, e.g., 34: “'Good' like 'bad' is essentially an attributive adjective.... There is no such thing as being just good or bad, there is only being a good or bad so-and-so." As McInerny later explained the point, "the only way we can figure out what is meant by calling someone a good philosopher is to go into what it is to be a philosopher" (Ethica Thomistica, 51).

6 Geach, "Good and Evil," 37. Thus Geach himself accepted the fact-value gap, even as he sought a way around it to defend naturalism. This admission from Geach ought, I think, to be an embarrassment to McInerny, who summarizes the factvalue gap ("there is a gap between fact and value that cannot be closed by citing facts about the valued thing") and ridiculed those who accept such a gap ("alas we know we are doing philosophy when we find ourselves in such a Wonderland as this"), while on the same page appealing to this very essay of Geach's for "an effective countering of this dogma" (Ethica Thomistica, 50).

7 If this distinction should stand, it constitutes a rather serious challenge to Jensen, 
can observe the behavior of an organism and come to understand that it has particular, natural inclinations which move it to act for the sake of various ends. But such observation of inclinations is altogether different from actually experiencing desires for those ends. Observation of desire is apprehensive and belongs to the intellect; experience of desire is rooted in appetite. To experience a desire for a thing is ipso facto to care about it, and that, rather than mere observation of desire, is what allows it to serve as a motive for acting. To observe that something desires water is not the same as being thirsty; even to observe that one's own nature "desires" water does not necessarily guarantee that one actually wants to drink. This is why both contraception and periodic continence are intelligible: the agents experience a desire for acts per se apt for procreation, and they recognize that this act, which they explicitly desire, is in fact ordered by their biology to a further end which they do not explicitly desire. Thus, although they observe a desire (in the sense of recognizing a teleological order) to reproduce, they do not experience a desire for that end considered in itself.

The apprehension of good that corresponds to experienced desire is what can motivate an agent. This is the sort of good that is relevant in the fact-value gap: no set of factual propositions can move me to act without there being some experienced desire that those facts somehow bear upon. Just as no facts about a watch make me want a watch unless those facts are brought into relation with some desire that I actually experience, so neither can speculative facts about my nature and its teleology move me to pursue an object unless they are brought to bear on a desire that I experience. ${ }^{8}$

Such observations fit perfectly with a number of things that Aquinas says about the practical intellect. Aquinas holds that "that for which there is an appetite, namely the desirable, is the principle of the practical intellect," and he holds that the activity of prudence (which perfects practical reason ${ }^{10}$ ) always presupposes some appetite for the end: "Prudence

who argues that we learn what is good for us by observing our natural inclinations, in the same way that we learn the natural inclinations, ends, and goods of other things by observing the teleology implicit in their behavior (Knowing the Natural Law, 79-80).

8 One may object that the first case differs from the latter in that there is no natural inclination to own a watch, whereas there are natural inclinations to those things that make one a good human. But that some desires are natural and inescapable, while certainly important to a complete theory of natural law, is irrelevant to the point I am making presently_namely, that speculative knowledge cannot move an agent to act without being joined to an experienced desire.

$9 \quad$ In III de an., lec. 15, no. 4.

10 Summa theologiae [ST] II-II, q. 47, a. 2, corp. 
presupposes the moral virtues, by means of which the appetitive faculty is directed towards good." We do not even deliberate about how to attain an end unless we first will that end. ${ }^{12}$ Thus practical reason as it is informed by prudence, whose function is to arrange the means to the end, presupposes an actual appetite for the end, whereas, he specifically says, the speculative reason does not move us to act, because it says nothing of pursuit or flight. ${ }^{13}$

Because practical reason begins with experienced desire-because it starts with something we already care about and value-the practical intellect can directly guide the will: it shares-so to speak-a common language with the will, the language of actual, experienced desire. Its judgments about the means are always immediately and transparently related back to some end actually desired by the appetites; as Aquinas puts it, "since the desirable thing itself, which is the first thing considered by the practical intellect, moves, therefore the practical intellect is said to move, namely because its principle, which is desirable, moves," ${ }^{14}$ or again, "if both intellect and appetition are principles with respect to one and the same movement they must, as such, share the same specific nature; since a single effect implies always a single cause of precisely that one effect." ${ }^{15}$

\section{That Obligation Is Not Derived from Value}

In distinguishing the is-ought gap from the fact-value gap, I mean to say that moral obligation can be apprehended by an agent independently of any prior apprehension of desirability, and conversely that an apprehension of a thing's desirability does not, of itself, entail an obligation to obtain that thing. A number of philosophers have suggested that the is-ought gap can be bridged through an entailment of "ought" by "wants"; ${ }^{16}$ consider expres-

11 ST I, q. 22, a. 1, ad 3.

12 In III de an., lec. 15 , no. 4.

13 In III de an., lec. 16, no. 10; In VI eth., lec. 2 and 12; In III de an., lec. 14, nos. 19-20; In III de an., lec. 15, no. 3. Cf. ST I-II, q. 9, a. 1, ad 2.

14 In III de an., lec. 15, no. 4.

15 In III de an., lec. 15, no. 7.

16 Alastair MacIntyre, "Hume on 'Is' and 'Ought," Philosophical Review 68 (1959): 451-68, at 462-463; Max Black, “The Gap Between 'Is' and 'Should,” Philosophical Review 73 (1964): 165-81. See also G. E. M. Anscombe, "Modern Moral Philosophy," Philosophy 33 (1958): 1-19, at 5, 7, 15, and 18, and Geach, "Good and Evil," 39: "By what logical step can we pass from the supposedly descriptive sentence 'adultery is a bad human act' to the imperative 'you must not commit adultery'?... We must allow in the first place that the question, 'Why should I'? or 'Why shouldn't I'? is a reasonable question, which calls for an answer, ... and I think the only relevant answer is an appeal to something the questioner wants." 
sions of the sort, "if you want the job, you ought to apply (because applying is the only reliable means of getting what you want)." While "wants" may entail "ought," the "ought" it entails is not something most people would recognize as moral obligation-instead it is an "unemphatic," hypothetical, or prudential "ought." ${ }^{17}$ Desiring something is, quite obviously, not the same as being obliged to get it - in fallen nature, the appetites are not necessarily well ordered. Conversely, one may recognize a thing as morally obligatory without finding it desirable in itself.

It is because of this disparity between "wants" and (moral) "ought," between value and obligation, that one can find oneself struggling to do what one full-well knows to be right-a state that is possible precisely because what is known to be right is not necessarily desired to the same degree it is known to be right. ${ }^{18}$ Indeed this disparity is what makes formal sin psychologically possible: what I want is not necessarily what I am obliged to do, and what I am obliged to do is not necessarily what I most desire. Hence, the apprehension of value and the apprehension of obligation are distinct in actual human experience.

The difference between the fact-value gap and the is-ought gap has been previously noticed by Alan Gewirth:

The presence of choice and purpose in action, thus gives it a structure such that, from the standpoint of the agent, "I do X for purpose E" entails "X and E are good." Since the latter statement is a value-judgment, or at least the function of such a judgment, to this extent from the standpoint of the agent the "fact-value" gap, even if not the "is-ought" gap, is already bridged in action. ${ }^{19}$

Whether Geach's answer is a good answer or not depends, I think, on details which, he admits with candor and modesty, he has not developed: "On many points (e.g. the relation between desire and good ...), I certainly do not see clear" (42).

17 See Philippa Foot, "Morality as a System of Hypothetical Imperatives," The Philosophical Review 81 (1972): 305-16; repr. in Virtues and Vices and Other Essays in Moral Philosophy (Oxford: Oxford University Press, 2002), 157-73.

18 It is true, of course, that we frequently describe the moral norms that we recognize as our "moral values," but this seems to me an imprecise use of the term "value." If I believe it is morally wrong for a husband to cheat on his wife, this may justify the expression that I consider marital fidelity "a value," but that does not imply that I am immune to temptations to infidelity, nor even that I, personally, actually desire to be faithful. What it does imply is that I would be a hypocrite to commit adultery. But such hypocrisy is not only possible but quite common among humans.

19 Alan Gewirth, "The 'Is-Ought' Problem Resolved," Proceedings and Addresses of the American Philosophical Association 47 (1973-74): 34-61, at 51. 
Gewirth here notes that deliberate activity is necessarily predicated on some value, which motivates it; as Aquinas says, no one acts but for the sake of an end that is desired. ${ }^{20}$ But the sort of value that underlies and motivates all deliberate activity is not the same as a moral obligation. Although the very fact that an agent acts demonstrates the presence of value, desire, and inclination, and while the fact of deliberation already bespeaks some consciousness of goods as goods (that is, apprehension of things as able to satisfy those desires), nonetheless the fact of action does not necessarily imply any knowledge of obligation. What we value, care about, and desire is not necessarily virtuous, let alone obligatory. ${ }^{21}$ That I desire or value something is enough for me to act for its sake, but that I have such a desire-a potential motive for deliberate action-does not entail that that desire is in any sense morally normative or that it bespeaks a moral obligation. ${ }^{22}$

One might insist that the derivation of obligation from value works if we identify value not with what we in fact desire, but with what we ought to desire; after all, in discussing the natural law Aquinas is more likely to speak of the desirable than the desired. For example, Henry Veatch first summarizes Germain Grisez with apparent approbation- "[the goods to be pursued] are objects of inclination in the sense of being things that we ought to be inclined towards, or should be inclined towards, whether we actually are or not"-before asserting in his own voice, "one may say that good or bonum is defined ... not as that which simply is desired, but rather as that which is desirable, or ought to be desired," ${ }^{23}$ But this does not close the gap for two reasons. First, it is not what one ought to desire but what one actually desires that provides a psychological motive of action. Thus, Aquinas explicitly uses appetibile to describe both the true good (as apprehended by right reason) and apparent good (e.g., as apprehended by the senses against the apprehension of reason). For Aquinas, "the desirable" refers not just to what we ought to desire, but includes all that we actually

20 ST I-II, q. 1, a. 1, corp.

21 See for example, In IV sent., lib. 4, d. 49, q. 1, a. 3, qc 1, ad 4.

22 See a parallel discussion in William Matthew Diem, "Reasons for Acting and the End of Man as Naturally Known: Reconceiving Thomistic Axiology," American Catholic Philosophical Quarterly 93 (2019): 723-56, esp. 723-25.

23 Henry Veatch, "Natural Law and the 'Is'-'Ought' Question," Catholic Lawyer 26 (1981): 251-65, at 262-63; see also 264. McInerny also seems to make such a move: "We ought to desire what we desire in the sense that the object of our desire ought to deserve the formality under which it is desired, viz., perfective and fulfilling" (Ethica Thomistica, 37). 
desire, including what we desire wrongly. ${ }^{24}$ Obviously, if an agent actually desires something, then it is able to be desired, and it is therefore also able to motivate deliberate action. Secondly, the judgment of what one ought to desire-if it is to give rise to moral "ought"-must already be morally normative. So this move only pushes the problem back, failing to bridge the divide between value and obligation as it purported to.

A subtler response was offered by Geach, who acknowledges the problem even as he suggests a solution:

It can, I think, be shown that an action's being a good or bad human action is of itself something that touches the agent's desires. Although calling a thing "a good A" or "a bad A" does not of itself work upon the hearer's desires, it may be expected to do so if the hearer happens to be choosing an A. Now what a man cannot fail to be choosing is his manner of acting; so to call a manner of acting good or bad cannot but serve to guide action.... Calling an action good or bad does not depend for its effect as a suasion upon any individual peculiarities of desire..$^{25}$

This solution does not get us quite so far as it might at first seem to: we often act for the sake of ends beyond the act itself; action is routinely chosen only as a means to something further, ${ }^{26}$ and if we are choosing an act as a means, then in wanting a "good act," what we cannot help but want is an effective (one might say "prudent" or "shrewd") act—an act that will obtain the end for whose sake we are acting-which is not obviously the same as a morally good act. Of course, we can argue the further point that a truly effective act, a truly prudent act, is an act that brings us to our ultimate and most valued end-the happiness that we all necessarily desire and for whose sake we always act. With yet further argument, we might show that the truly effective act will, as it turns out, always be a morally good act. Certainly such an argument can be made (indeed Aquinas made one very much like $\left.\mathrm{it}^{27}\right)$, but making such an argument amounts to demonstrating

In III de an., lec. 15, nos. 9-10.

Geach, "Good and Evil," 40.

26 Admittedly, in some cases the end may itself be a form of activity (e.g., those playing a game may desire the very act of playing as an end and a debater may relish the argument itself), but even here, the end desired is usually the specific sort of act (e.g., playing the game or arguing), not acting simply. The fact we choose to act does not imply that we desire to perform good human acts as such, that is, in general.

27 ST I-II, q. 55, a. 3, corp. ("virtue implies a perfection of power; . . every evil is a 
to a person that, whether he realizes it or not, what he really implicitly wants above all else, what will really satisfy his deepest desires and make him truly happy, is to be virtuous. But the very fact that one must establish this by argument, the fact that one must persuade a person to desire virtue explicitly by showing that only virtue can satisfy man's deepest desire, proves that the concept of obligation (or of moral uprightness more generally) and the concept of value are distinct: To apprehend something as obligatory or morally right is not the same as apprehending it as fulfilling an experienced desire. Showing that morally good action is-precisely in being morally good-a uniquely effective means of achieving the happiness that one cannot help but desire requires proof: It has to be shown, as Geach himself admits, for it is not immediately obvious to most agents that a truly effective act is precisely the same as a morally good act.

To deny this distinction between value and obligation, to hold instead that obligations arise from a prior value, seems to me to be disastrous to the project of ethics. I have already noted that the psychological possibility of sin requires a distinction between value and obligation. As but one further example, without this distinction between "ought" and "wants," the fourfold distinction of continent, incontinent, virtuous, and vicious collapses. $^{28}$

In making such a distinction between the notions of "good" (in the sense of "desired by the agent" and therefore a possible motive of deliberate action) and "morally obligatory," I am cutting across the grain of the contemporary dispute over "is" and "ought" in Aquinas's natural law theory. Although there is a fierce, decades-long debate among Thomists over whether "ought" is derived from "is," 29 both camps of Thomistic natural lawyers concur in rooting our apprehension of moral "ought" directly in some prior apprehension of value or good.

Those who insist that "ought" can be derived from "is" hold that we

weakness"), and II-II, q. 145, a. 3, ad 3, explaining Ambrose and Cicero: "Nothing incompatible with honesty can be simply and truly useful, since it follows that it is contrary to man's last end, which is a good in accordance with reason; although it may perhaps be useful in some respect, with regard to a particular end."

28 See In III de an., lec., 14, nos. 22-23.

29 The principal parties to this debate are the New Natural Lawyers-John Finnis, Germain Grisez, and their numerous collaborators, including Robert George and Christopher Tollefson-who insist that practical "ought" knowledge cannot be derived from speculative "is" knowledge, and their critics: Veatch, Russell Hittinger, McInerney, Long, Jensen, and others. Although he defends a distinct theory of natural law, Martin Rhonheimer concurs with the New Natural Lawyers in maintaining a sharp distinction between practical and speculative knowledge. 
begin with a speculative understanding of human nature, of what is perfective of human nature, or of what is the telos of human nature. From this understanding of human nature in general we can, they hold, immediately grasp that those things we understand to be perfective of humans are goods and therefore, too, things that we, as humans, ought to pursue. Thus Robert George summarizes the "neo-scholastic" counterposition to New Natural Law theory:

A sound natural law ethics [the critics hold] derives moral norms from methodologically antecedent knowledge of the nature of man and of man's place in nature. According to this approach, metaphysics-in particular that branch of metaphysics that studies man-precedes ethics.... One discovers what one ought to do by understanding the facts about human nature. ${ }^{30}$

On the other hand, George writes that the New Natural Lawyers, who insist that there is an is-ought gap,

reject [the neo-Scholastics'] approach . . . they maintain that it involves "the naturalistic fallacy" of purporting to infer moral norms from facts about human nature. Logically, a valid conclusion cannot introduce something that is not in the premises.... [Moral norms] cannot be derived from premises (e.g., facts about human nature) that do not include reasons for action. According to Grisez and others, natural law theory need not-and a credible natural law theory cannot-rely on this logically illicit inference from facts to norms. $^{31}$

Thus, according to the New Natural Lawyers, moral norms can only be derived from premises that already contain "reasons for action"; these prior reasons for action, the New Natural Lawyers hold, are the basic human goods, which are apprehended by practical reason as self-evidently desirable. Thus, Christopher Tollefsen writes: "Practical reason ... grasps as self-evidently desirable a number of basic goods ... described as constitutive aspects of genuine human flourishing. ... As grasped by practical

30 Robert P. George, "Natural Law and Human Nature," in Natural Law Theory: Contemporary Essays, ed. Robert George (Oxford: Oxford University Press, 1992), $31-4,1$ at 32 and 33. He specifically refers to R. Hittinger, L. Weinreb, H. Veatch, R. McInerny.

31 George, "Natural Law and Human Nature," 32-33. 
reason, the basic goods give foundational reasons for action to human agents." ${ }^{32}$ What is significant, for present purposes, is not the intermediate steps in the derivation of the first moral norms from the basic goods, but simply the fact that the first moral obligations are (according to the theory) logically derived from "self-evidently desirable," "basic human goods," which already present us with "foundational reasons for action," and which we cannot help but care about. Thus, John Finnis notes that a deduction of "ought" requires advertence to some "desire or interest of the agent's that might be satisfied by acting rightly,"33 and George notes that, "to conclude to specific moral norms, ... one's premises must include reasons for action that are more fundamental than those norms." "We cannot," he says, "deduce or infer reasons for action from premises that do not include reasons for action. We cannot deduce or infer basic reasons for action from anything." ${ }^{35}$

Thus both schools root our apprehension of obligation immediately in a prior apprehension of value or good, in the sense of a potential motive or "reason for action." This shared commitment is seen most readily in the conflation of the fact-value gap and the is-ought gap; as we already noted, it is commonly presumed that deducing values from facts is equivalent to deducing moral norms from facts-although the parties differ insofar as one accepts such deduction as foundational to ethics and the other rejects it as fallacious. Consider, for example, Long's retort to Finnis's insistence that there is an is-ought gap: "If nature is ordered hierarchically toward certain ends, ... then knowledge of these natural ends will itself contain implicit reasons for action." 36 Or again, consider McInerny's puzzling assertion that "merely factual desire, such

32 Christopher Tollefson, “The New Natural Law Theory," Lyceum 10 (2008): 1-17, at 2 .

33 Finnis, Natural Law and Natural Rights, 40-41.

34 George, "Natural Law and Human Nature," $41 \mathrm{n} 20$.

35 George, "Natural Law and Human Nature," 38.

36 Steven A. Long, "Through the Analytic Looking Glass," The Thomist 65 (2001): 259-300, at 268. While one must note that he is merely responding to the objection as formulated by Finnis, my point remains that in recent Thomistic literature moving from "is" to "ought" is routinely understood as equivalent to moving from facts to reasons or motives for acting. I should add that, while I concede that speculative knowledge of the good might elicit desire (or as Long elsewhere puts it, "incite" or "spark" [Teleological Grammar, 73, 75]), still, I insist, first, that eliciting is different from entailing and, second, that desire is different from "ought." One might locate an antecedent to Long in Geach, "Good and Evil," 42: "I have argued that the characteristic of being a good or bad human action is of itself bound to influence the agent's desire." 
as is required for the Humean problem, does not exist" ${ }^{37}$ (although Hume's problem says not a word about desire). This shared presumption is also made clear by their unanimous teaching that a moral obligation is a necessary means to a necessary end (where "necessary end" names something inescapably desired by the agent, e.g., happiness, flourishing, or "integral human fulfillment"). ${ }^{38}$

This shared assumption is quite natural for at least two reasons. The first is that (as McInerny rightly notes ${ }^{39}$ ) the locus classicus of the Thomistic natural law tradition-Summa theologiae [ST] I-II, q. 94, a. 2-essentially enshrines the implication of "ought" by "wants" in the first principle of practical reason and then derives the first "precepts" of the natural law immediately from our natural inclinations to various goods:

The first principle of practical reason is ... "good is to be done and pursued, and evil is to be avoided." ... Hence it is that all those things to which man has a natural inclination, are naturally apprehended by reason as being good, and consequently as objects of pursuit, and their contraries as evil, and objects of avoidance ... Wherefore according to the order of natural inclinations, is the order of the precepts of the natural law. ${ }^{40}$

By identifying those things to which man has a natural inclination we can immediately conclude that those things "are to be pursued," and the arti-

37 McInerny, Ethica Thomistica, 38.

38 Thus Finnis, Natural Law and Natural Rights, 45-46: "Aquinas ... treats obligation as the rational necessity of some means to ... an end or objective (i.e., a good) of a particular sort. What sort? Primarily ... the good of a form of life which .. . renders one a fitting subject for a friendship of the being whose friendship is a basic good that in its full realization embraces all aspects of human well-being, a friendship indispensable for every person." For a recent example of this teaching in neo-Scholastic Thomists, see Jensen, Knowing the Natural Law, 167-74; true, Jensen explicitly denies that the hypothetical "ought" is "derived from the desires of the individual," but he also holds that "since everyone wants some of the goods of nature, nature can impose a universal hypothetical necessity" (173; emphasis mine). This explanation of obligation has a history; it can be found in, e.g.: Austin Fagothey, Right and Reason, 2nd ed. (Charlotte, NC: TAN Books, 2000), 198-201; Michael Cronin, The Science of Ethics, vol. 1, General Ethics (Dublin: M. H. Gill and Son, 1909), 218-19; and Luigi Taparelli, Saggio Teoretico di Drito Naturale Appoggiato sul Fatto, 2nd ed. (Livorno: Vincenzo Mansi, 1851), 91-92. McInerny, Ethica Thomistica, 38.

40 Translation of the Summa theologiae that of the Fathers of the English Dominican Province, second revised edition, 1920. 
cle appears to identify this judgment with the first moral precepts of the natural law. ${ }^{41}$

The second reason is that Aquinas says, quite explicitly and on multiple occasions, that the necessity which moral obligation places on the will is the necessity of the end-that is, the hypothetical necessity of willing some means in order to attain some end. Thus he writes: "The other [kind of necessity, the sort that is compatible with voluntariness] arises from the obligation of a 'command,' or from the necessity of obtaining an end, when, to wit, a man is unable to achieve the end of virtue without doing some particular thing. ${ }^{\prime \prime 2}$ And, he explains the power of conscience to bind the will by appeal to the necessity of the end:

The other necessity is conditional, on the presupposition, that is, of an end to be attained. In this way, necessity is so imposed on one that, if he does not do a certain thing, he will not receive his reward. ... [This sort of necessity] can be imposed on the will, so that one must, for example, choose this means if he is to acquire this good, or avoid this evil. ${ }^{43}$

Hence Aquinas seems to identify moral obligation with the hypothetical necessity derived from our desire for an end, and so the two schools of natural law theorists seem to be well justified in their common teaching that the binding power of obligation is derived from value.

We will return to these texts below, but note, for the moment, that these accounts, as different as they are, universally concur in asserting that some apprehension of the agent's good immediately underlies every apprehension of obligation: we apprehend obligation only because we first apprehended our good as humans. Both sides in the debate take it for granted that obligations are reasons for acting derived from prior a apprehension of what is good and desirable to human agents. The principal difference between the two schools, which gives rise to the dispute, is how they hold that we come to apprehend our goods in the first place: do we deduce them from speculative knowledge of human nature or does practical reason itself simply apprehend them as self-evidently desirable?

But if my contention is correct, then this shared point of departure

41 I have elsewhere argued that Aquinas is not, in fact, speaking of the natural law as a moral law here. See William Matthew Diem, "The Analogy of Natural Law: Aquinas on First Precepts," The Heythrop Journal, forthcoming.

$42 \quad S T$ II-II, q. 58, a. 3, ad 2. Cf. ST I, q. 19, a. 3, corp.; I, q. 82, a. 1.

43 De veritate, q. 17, a. 3, corp.; cf. ST I-II, q. 99, a. 5, corp. 
must be mistaken, for it conflates value and obligation and treats the isought gap as the fact-value gap. I, however, insist that obligation is apprehended independently of any consideration of the agent's good or end or desire. Thus, for example, the question whether I morally ought or ought not to kidnap and vivisect strangers for the thrill of the experience can be answered without ever considering whether such behavior is good for me or fulfills one of my desires or is conducive to my perfection; such questions are utterly irrelevant to determining its moral rightness. ${ }^{44}$ Whether an act will satisfy some desire of mine-fulfilling me, and bringing me closer to happiness-will be important in determining whether it is possible for me to choose that act, but that is a distinct, second question, and that second question need not be answered before I can determine whether the act is morally right or wrong in the first place. ${ }^{45}$ I need not suspend my moral judgment of such heinous acts until I have determined their likelihood of making me happy. The only good one must consider to judge such an act of wanton torture simply wrong is-I insist-the good of the potential victim. ${ }^{46}$

44 New Natural Lawyers may retort that, on their account, the goods in question are not specifically my goods, but are general human goods that remain good regardless of who possesses each instance of each good. My reply to this is twofold: First, only my goods-those things for which I have some appetite, inclination, or desire-move me to act. Other persons' goods, considered as such, do not constitute self-evident reasons for me to act (altruistic behavior is possible when, through love, we identify with the other and therefore come to view and desire the good of the other as our own); The good of another, as such, does not necessarily correspond to any desire I experience. Second, if we consider the quotation from Finnis in note 38 above, it is clear that the good in question is "indispensable" to each agent precisely insofar as it is a good of the individual agent. The point is also clear in Natural Law and Natural Rights, 40-41, quoted in note 4 above.

45 This emphasis on my desires is not to exclude or ignore common goods. While one may have a natural desire for common goods, such goods are motives for me to act only to the extent that $I$ actually have some desire or inclination to them. For example, friendship may move me to seek the other's good for the other's sake, but I am so moved only if I already have a desire and inclination for friendship.

46 Determining what, specifically, is good or bad for the other may depend on my knowledge of what is good for me (I do not want to be vivisected, and therefore, in the absence of a relevant distinction between us, it is probably harmful for other humans to be vivisected). In this limited and specific respect my good and my desires may end up being relevant to answering the question of what is right or wrong for me to do. My point, however, survives this concession: I do not need to consider whether vivisecting (actively) will or will not be an effective means to achieving my eudaemonia or fulfillment or happiness to determine whether I ought or ought not vivisect another. Consideration of $m y$ good, as such, is not relevant; it is relevant only to the extent that it gives me an insight into the other's good. 


\section{Obligation and Value in Aquinas's Account of Practical Reason}

Thus far I have argued, first, that value-such as can serve as a motive for action-cannot be derived from speculative knowledge of fact, and second, that such value is, in principle, distinct from obligation. Although I have suggested along the way that Aquinas concurs with these contentions, we must now consider Aquinas's treatment of value and obligation in practical reason more systematically.

When we turn to Aquinas's treatment of practical reason, we encounter an apparent circle. On the one hand, Aquinas frequently insists that practical reason takes its first principles from the appetites, while on the other hand, he insists just as frequently that the rectitude of the appetites consists in their being conformed to right reason. Thus, the practical intellect seems both to follow and to lead the appetites.

For example, he holds that practical intellect follows appetite because the end desired by the appetites stands to the practical intellect as speculative principles stand to the speculative intellect. This is why prudence-or "right reason about things to be done, ${ }^{\prime \prime 7}$ which perfects the practical intellect-presupposes the other moral virtues, which perfect the appetites. ${ }^{48}$ It is equally why false prudence (as found, for example, in a "good robber") is possible: true prudence presupposes the uprightness of desire effected by the other moral virtues, particularly justice. ${ }^{49}$ This is also the crux of his distinction between prudence and art: prudence presupposes the actual desire for the end, whereas art merely includes knowledge of how to bring about an end without regard for whether that end is desired; thus the one who willingly "sins" against his art more fully possesses the habit of his art than the one who inadvertently sins against his art, though it is the opposite with prudence. ${ }^{50}$ Hence, practical reason as informed by prudence presupposes appetite.

But, showing that reason leads the appetites, he writes, "the end concerns the moral virtues, not as though they appointed the end, but because they tend to the end which is appointed by natural reason," 51 and again, "the proper end of each moral virtue consists precisely in conformity with right reason." 52

47 ST I-II, q. 57, a. 4, corp.

$48 S T$ I-II, q. 65, a. 1, corp. See also $S T$ I-II, q. 57, a. 4, corp.

$49 \quad S T$ II-II, q. 47, a. 13, esp. ad 2. See also, ST I-II, q. 57, a. 3, ad 2.

50 ST I-II, q. 57, a. 4, corp. See also I-II, q. 57, a. 3, corp., ad 2 and ad 3, and De veritate, q. 2, a. 8, corp.

51 ST II-II, q. 47, a. 6, ad 3 (Emphasis mine).

s2 ST II-II, q. 47, a. 7, corp. 
So we are left with a question: Does practical reason lead the appetites or does it follow the appetites? Does practical reason take the ends from the appetites, or does practical reason appoint the ends to the appetites?

The apparent circularity, but also the beginning of its resolution, can be seen nicely when he writes that, "reason, as apprehending the end, precedes the appetite for the end: but appetite for the end precedes the reason, as arguing about the choice of the means, which is the concern of prudence." 53

The solution that the text suggests is that there are two different functions of reason in guiding action. The first is in apprehending the end, the second is in arranging the means to that end (which, he says here and elsewhere, is the work of prudence). The intellect's act of apprehending the end is prior to appetite, but its act of arranging the means to that end follows the appetite for the end.

The reason which "appoints the end" to the appetites is, Aquinas explicitly says, synderesis, not prudence: "Natural reason known by the name of 'synderesis' appoints the end to moral virtues, ... but prudence does not do this." ${ }^{54}$ Synderesis is the intellectual habit that apprehends the first moral precepts, the first norms of the natural law,${ }^{55}$ which norms conscience then applies to individual acts. ${ }^{56}$ And as we just saw, synderesis appoints the end to the appetites, while prudence presupposes the end desired by the appetites. ${ }^{57}$

Hence we have two practical functions of reason. One precedes appetite, begins in synderesis, first apprehends moral law, and determines the end of the moral virtues. This is the "right reason" that is the measure of moral good and in comparison to which we determine what is virtuous; this is the practical reasoning whose final judgment is conscience. The other sort of practical reasoning follows appetite, takes the ends desired by the appetites as its principles, and arranges the means to those desired ends, and this is the practical reasoning that is informed by prudence.

We can also see this distinction drawn when Aquinas asserts that there are two different sets of principles operative in practical reason-universal and particular - and that only the latter of these is subject to error.

53 ST I-II, q. 58, a. 5, ad 1. He makes a similar point in I-II, q. 19, a. 3, ad 2.

54 ST II-II, q. 47, a. 6, ad 1. But compare this with I-II, q. 66, a. 3, ad 3, where he seems to say otherwise. Though I am here distinguishing two functions of practical reason, as I will note below, in practice, the two functions are closely bound together.

55 De veritate, q. 16, a. 1 , corp.

56 De veritate, q. 17 , a. 1 , ad 1.

57 ST II-II, q. 47, a. 6, ad 1, ad 3. 
As to universal principles of action, man is rightly disposed by the natural understanding of principles, whereby he understands that he should do no evil. . . . Consequently, as by the habit of natural understanding, ... man is made to be rightly disposed in regard to the universal principles of action; so, in order that he be rightly disposed with regard to the particular principles of action, viz. the ends, he needs to be perfected by certain habits, whereby it becomes connatural, as it were, to man to judge aright to the end. This is done by moral virtue. ${ }^{58}$

The universal principles appear to be normative (e.g., "that one should do no evil"), and they are grasped by "natural understanding of principles" (which, I believe, must refer to synderesis). The particular principles of practical reason are the ends themselves that are actually desired by the appetites informed by the moral virtues. Elsewhere he is perfectly clear that, on the one hand, the actually desired ends (the principles of practical reason as it follows appetite and arranges the means to the end) can be evil in those who lack the moral virtues (giving rise to false prudence), while on the other hand, he is equally clear that synderesis (which provides the first principles to practical reason preceding and ruling appetite) is immune from error. ${ }^{59}$ Thus, we clearly find in Aquinas two distinct functions of "practical reason," each with its own first principles.

The distinction between these two functions of practical reason corresponds perfectly with the distinction I previously drew between value and obligation: The practical reason that leads appetite treats obligation, while the practical reason that follows appetite treats value. Synderesis provides conscience its first moral principles, its most fundamental and general obligations or "ought" statements; it provides us-Aquinas says explicitlywith our first apprehension of the precepts of the natural law whereby we distinguish right from wrong. But that practical reasoning is distinct from the practical reasoning that begins with an object desired by the appetites and arranges the means to it. The practical reason that determines what one (morally) "ought" to do and the practical reason that determines how one (prudentially or shrewdly) "ought" to act in order to achieve what one desires are distinct and discrete. In other words, for Aquinas, moral "ought" (apprehended by synderesis and applied by conscience) and

58 ST I-II, q. 58, a. 5, corp.

59 Quodlibet XII, a. 3, corp.; De veritate, q. 16, a. 2, corp.; q. 16, a. 1. Cf.: ST I, q. 79, a. 12, corp.; De malo, q. 3, a. 12, ad 13; q. 16, a. 6, ad sc 6; In II sent., d. 24, q. 2, a. $4, \operatorname{ad} 3$. 
prudential or hypothetical "ought"-which tells us how to attain what we desire-are distinct. ${ }^{60}$

But if obligation and value are distinct and if one can know what one morally ought to do independently of any desire to do it, how can knowledge of obligation guide action? If obligation is not itself a motive for action, how can knowledge of what one ought to do ever provide a reason, let alone an overriding reason, for acting morally?

Knowledge of obligation can become a motive for action because man has a natural desire to live reasonably, that is, virtuously. Hence Aquinas notes: "There is in the will a natural appetite for good in accordance with reason.... It is therefore evident that all virtues are in us by nature, according to aptitude and inchoation, but not according to perfection," ${ }^{\prime \prime 1}$ and elsewhere, "there is in every man a natural inclination to act according to reason: and this is to act according to virtue." ${ }^{\prime 2}$ This inclination is manifested in the phenomenon we call in English the "pangs of conscience" or in what Aquinas calls the "worm of conscience": ${ }^{63}$ we experience knowledge of guilt as painful because guilt frustrates a natural desire, namely, the natural desire to live according to reason. Thus, conformity to the dictates of right reason (i.e., to the judgments of conscience) is itself apprehended as desirable (in the sense of being an object of experienced desire and thus having what it takes to motivate deliberate activity). Obeying the judgments of conscience fulfills man's natural desire to live according to reason, and therefore it can always be taken sub specie boni and become a value that moves the will.

The reason we are tempted to identify the is-ought gap and the factvalue gap is that there is a clear and close relationship between these two functions of practical reason. Knowing what I morally ought to do is irrelevant trivia if it cannot move me to act. The whole point of obligation is to direct our voluntary actions, so the suggestion that obligations do

60 For the difficulties in determining the relationship between conscience and prudence, see Pius Mary Noonan, "Auriga et Genetrix: le rôle de la prudence dans le jugement de la conscience," Revue thomiste 114 (2014): 355-77, 531-68.

${ }_{61} S T$ I-II, q. 63, a. 1, corp. The same point is often repeated: e.g., De veritate, q. 16, a. 1, ad 9; ST II-II, q. 47, a. 7, corp.; a. 6, corp.

$62 S T$ I-II, q. 94, a. 3; Remember the general principle from the prior article: "Since, however, good has the nature of an end, and evil, the nature of a contrary, hence it is that all those things to which man has a natural inclination, are naturally apprehended by reason as being good, and consequently as objects of pursuit, and their contraries as evil, and objects of avoidance."

63 In IV sent., d. 15, q. 1, a. 3, qc 5, corp.; ST Suppl., q. 67, a. 2. I am aware that this is an analogous use of "conscience," but I am concerned with the thing not the word. 
not of themselves serve as motives of action seems too absurd to merit consideration. But although there is a close relation between them-such that what is judged right by reason is ipso facto also the object of a natural desire-the question of what reason has determined is to be done and the question of whether what is to be done is somehow desirable remain, in principle, distinct. We do not grasp that an act is obligatory because we first grasp that it is somehow desirable. Rather, what reason judges is to be done is also grasped as desirable precisely because it is uniquely reasonable-that is, because reason has determined that it is, unqualifiedly, to be done.

We can see this in Aquinas's treatment of the upright (honestas), which he holds is the same as the virtuous. ${ }^{64} \mathrm{He}$ argues that everything upright is both naturally pleasurable to $\operatorname{man}^{65}$ and naturally desired by man, precisely because the upright is conveniens rationi. ${ }^{66}$

It is precisely in the logical order that it posits between the apprehension of obligation and the awareness of a relevant natural desire that the theory I am espousing is distinct from the interpretations of natural law I earlier criticized. I hold that we first apprehend what is right and only then do we naturally recognize that what is right is by that fact also desirable. The theories I earlier rejected hold that our apprehension of obligation follows from our prior apprehension of goodness and desirability: we first apprehend a good (as desirable) and from that apprehension we somehow derive an obligation. But I insist that I do not need to consult my desires or my teleology to determine what I am obliged to do or not do. ${ }^{67}$ The recognition that doing what I am obliged to do satisfies a particularly important natural desire is a logically discrete step that follows on my recognition that the act is obligatory in the first place; the desire does not constitute that obligation as obligatory, it follows on my apprehension of the act as obligatory. Not only can I desire something without being obligated to get it, but I can also be obligated to do something that I do not naturally find desirable considered aside from its being obligatory, reasonable, and virtuous, just as the useful is not necessarily pleasant in itself, aside from its being useful. ${ }^{68}$

What I have proposed is consistent with how Aquinas describes conscience's power to bind us in De veritate. After asking whether

64 ST II-II, q. 145, aa. 1-3.

65 ST II-II, q. 145, a. 3, corp.

66 ST II-II, 145, a. 3, ad 1; a. 2, ad 1.

67 Of course, my (natural) desires may be an important source of content, as is clear from the "golden rule." See note 46 above.

68 In IV sent., d. 49, q. 1, a. 1, qc 4, ad 4; ST II-II, q. 145, a. 3. 
conscience binds, he replies, yes, it binds us: by making us aware of the precept of a ruler, it imposes on the will a necessity from without and so compels us to choose what we do not desire; nonetheless, it binds us only by stipulating a condition for achieving good and avoiding evil. ${ }^{69}$ Here we find both sides of the problem: we are bound by a lawgiver to do what we do not otherwise wish to do, but the will can only be bound in a conditional or hypothetical sort of way-hence it remains free. On the condition of obtaining what specific end is the will thus bound? What is the good that can only be obtained through obedience to conscience and conformity to law? Moral obligation, he explicitly says elsewhere, binds the will insofar as "a man is unable to achieve the end of virtue without doing some particular thing." ${ }^{70}$ But virtue is nothing else than living in conformity with right reason. We desire to live reasonably, and this desire can only be fulfilled by doing what "reason dictates ... must be done," conscience. Virtue, he quite explicitly says, is natural to us not insofar as man is naturally inclined to each virtuous act, but insofar as man has a general, natural inclination to live according to reason. ${ }^{72}$ Indeed, Aquinas notes that the first order to which the human will is subject is the order of his own reason, an order that is enforced through the pangs of conscience. ${ }^{73}$ Our conscience troubles us because we violated the judgment of reason in doing what we knew was wrong; we do not know that something is wrong because we first anticipated that our conscience would trouble us if we were to do it.

Thus the link between the two roles of "practical intellect" is found in the rational appetite. One function of the practical intellect guides the will; in apprehending and applying moral norms, it establishes the conditions of fulfilling our natural appetite for living according to reason. The other function of the practical intellect arranges the means to the end desired by the will. ${ }^{74}$ The intellect apprehends moral norms (initially

\footnotetext{
De veritate, q. 17, a. 3, corp.

$S T$ II-II, q. 58, a. 3, ad 2 (emphasis mine). Cf. ST I-II, q. 99, a. 5, corp.

ST I-II, q. 99, a. 5, corp.

72 ST I-II, q. 94, a. 3, corp.: "If we speak of virtuous acts, considered in themselves, i.e. in their proper species, thus not all virtuous acts are prescribed by the natural law: for many things are done virtuously, to which nature does not incline at first; but which, through the inquiry of reason, have been found by men to be conducive to well-living."

73 ST I-II, q. 87, a. 1, corp.

74 Though even here the intellect is guiding the will, although with respect to the means rather than the end. Hence, there is in fact a constant interplay between intellect and will.
} 
though synderesis) and, applying these norms, determines which specific acts are and which are not in conformity with right reason (through conscience). Because we have a natural inclination to live according to reason, that which conscience has determined is to be done ipso facto also acquires the speciem boni, so that it can be willed. Of course, this inclination to live according to reason is only one of many natural inclinations, ${ }^{75}$ and there are many particular things that reason demands of us that we do not naturally desire in themselves. ${ }^{76}$ It is therefore possible for us to face a moral struggle-to find ourselves torn between competing goods-and even to sin by willfully violating conscience. ${ }^{77}$ In either case, one can then will to deliberate, making use of reason to arrange the means to the end willed-this is the realm of prudence. Synderesis thus leads prudence, ${ }^{78}$ but only through the mediation of right appetite.

\section{From Speculative to Practical}

If "practical reason" does not only extend to some one and unified process of reasoning, if instead, there are at least two essentially disparate processes of reasoning that Aquinas labels "practical"-one that precedes and guides the appetite for the end by appointing the end of the moral virtues, and another that follows and is led by the appetite for the end, taking as its principles the ends actually desired by the appetites, and arranging the means to those ends-and if, moreover, each has its own first principles, then the famous Thomistic disputes over the is-ought problem have their origin in a fundamental confusion.

Once our distinctions have been drawn, the is-ought problem loses its moment. The reason the is-ought problem was a problem for Thomists was that, as I showed above, we expected our answer to the is-ought gap equally to bridge the fact-value gap. We expected moral norms to touch desire and immediately provide the will with reasons for acting. Our search was destined to fail: if value is in principle distinct from obligation, then there can be no one thing that explains, with equal immediacy, both our recognition of obligation and our apprehension of value. We expected our apprehension of obligation to provide our will with a decisive reason to

75 In III de an., lec. 15, no. 10, where he distinguishes the appetible into apparent good and true good based on whether the appetible is good in the judgment of reason or good only on account of an appetite or phantasm against the judgment of reason.

76 ST I-II, q. 94, a. 3, corp.

77 De veritate, q. 17 , a. 1 , ad 4.

78 ST II-II, q. 47, a. 6, ad 3. 
do what is right, when in fact moral obligation is only decisive to the intellect. Indeed, this disparity is the heart of sin and fault: formal sin, violation of conscience, is precisely the refusal of the will to do what the intellect has judge absolutely and unqualifiedly to be done. ${ }^{79} \mathrm{Sin}$ is nothing else than the will's nolo to intellect's debeo. To conflate value and obligation is to destroy the notion of sin.

But, if value and obligation are two discrete concepts, treated by two fundamentally different intellectual processes, starting from two radically different sets of principles, then the famous difficulties evaporate. ${ }^{80}$ Once we have made this distinction, what follows is that there is no need to deny that a speculative apprehension can immediately give rise to an apprehension of moral norms: moral norms are not value statements, and so the gap between fact and value need not be overcome in deriving moral norms. Moral norms do not immediately and of themselves provide a motive to the will, neither do they immediately, of themselves touch desire or inclination. And if synderesis need not bridge the fact-value gap in discovering the first moral norms, then it is free to derive "ought" from speculative apprehension.

The specific class of apprehensions I have in mind are those that pertain to owing something to someone. As an example, ${ }^{81}$ the concept of vowing seems to me a speculative notion, and understanding what a vow is appears to me to be manifestly a work of the speculative intellect. At the same time, whether someone, in fact, made a vow or not is straightforwardly

79 Jensen, following Foot, notes this disparity, though he, like early Foot, takes it as a sign of the incoherence of the notion of "moral ought" (Knowing the Natural Law, 151 and 174).

80 Making this distinction is not attacking a straw man. A recent example of this confusion can be seen in Jensen, Knowing the Natural Law, 126-49 (ch. 7), esp. 144 , where he takes prudence as essentially exhaustive of practical reason and therefore as the way we come to know obligation. (In light of this, we should hardly be surprised that Jensen concludes that all "ought" statements are hypothetical, unemphatic, or prudential; if we assume that prudence is coextensive with practical reason and that therefore "ought" statements arise from prudence, then naturally we will find only prudential instances of "ought.") The problem in this approach is that prudence is a function of the practical reason that follows appetite, not the practical reason that guides appetite through apprehension of natural law. In here criticizing Jensen on this point, I equally criticize myself: in my review of Jensen, I followed him in this move; see my review Knowing the Natural Law in Studies in Christian Ethics 29 (2016): 356-59.

81 What follows is inspired by John Searle, "How to Derive Ought from Is," The Philosophical Review 73 (1964): 43-58, at 44. While inspired by his work, I do not mean to endorse all that Searle has said on this issue. 
a question of fact. But, on the other hand, that speculative concept of vowing is meaningless if it does not include the idea of placing oneself under an obligation or, equivalently, of placing oneself in a relationship of owing something to another. If such concepts as obligation and owing are removed from the concept of vowing, then nothing is left in the notion of vowing. Similarly, if one owes something to another, one ought, so far as reason is concerned, to render it to him. The result is that a person who does not understand that (all things being equal) one ought to fulfill one's vows does not understand what a vow is.$^{82}$ Of course, knowing what a vow is and knowing that one ought to do what one has vowed do not imply that one wants to fulfill his vows, precisely because the notion of obligation does not of itself imply desire.

As another example, consider property. The concept of property, just in itself, seems to me a speculative concept, while holding title to some property is, in principle, a matter of fact. But it is a matter of fact that immediately entails that others have certain duties (not, for example, to interfere with the owner's use of his property, absent some compelling justification). ${ }^{83}$ Owning something is meaningless if it does not entail some rights over against other agents with respect to the thing owned.

I do not mean to dismiss the complexity of these topics. One may entertain perfectly sound questions about what matters of fact establish a title

82 Of course, one may deny that there are such things as vows, i.e., communicative acts that place the speaker under an obligation; this amounts to rejecting the institution of vowing (see Charles Pigden, "Hume on Is and Ought: Logic, Promises and the Duke of Wellington," in The Oxford Handbook of Hume, ed. Paul Russell [Oxford: Oxford University Press, 2016], 401-15, for a summary of these issues). And such a one may even persist in speaking of "vows" in a purely descriptive sense while explicitly denying that they impose any obligation on a person. But such a person is really denying the intelligibility of vowing as a concept. That person's attitude is precisely to insist that the notion of vowing is incoherent. This is what I mean by saying the person does not understand the term. And although he might well be able to use the word competently, he may also choose to surround it with scare quotes to make clear that he rejects the intelligibility of the concept that the word is meant to express: it is to him a mere label, and he doesn't actually believe that the person has made a vow. As an analogous example, one might deny the intelligibility of the institution of slavery-holding that it is simply incoherent to believe that a person actually can really be mere property-and yet be able to use the word competently in light of a legal and social institution.

83 See the discussion of speculatively practical knowledge in Reginald Garrigou-Lagrange, "Remarks Concerning the Metaphysical Character of St. Thomas's Moral Theology, in Particular as It Is Related to Prudence and Conscience," trans. Matthew K. Minerd with notes, Nova et Vetera (English) 17 (2019): 245-70, at 266-69. 
to some property, and the answers to such questions may be complicated, contingent, and culturally conditioned. The point, however, is that once we acknowledge that there is such a thing as real, honest-to-God ownership of property, rather than a mere social convention, we can immediately conclude that, in whatever cases that relation of ownership applies (which is, in principle, a question of fact), something is owed to the owner, and what follows from such owing is that (ceteris paribus) it would be unreasonable not to render what is owed him. The point is a tautology: we owe to others what is their own. It is worth noting, here, that if we expand the notion of property to include not just chattels but anything that a person can call his own in some meaningful and objective sense, and if we expand the corresponding notion of owning to the notion of dominium, then we can quickly account for the vast majority of traditional natural rights (like a person's right to life) and indeed all the precepts of the Decalogue.

In fact, I think this derivation of obligation from notions like owing or owning is precisely the reasoning behind Aquinas's somewhat perplexing example in $S T$ I-II q. 94, a. 4: One cannot assent to the descriptions that this is another's property and that one holds it in trust without also recognizing that it is due to the owner and that it would be unreasonable (ceteris paribus) not to return it to him. And to recognize that this thing one has is due to the another is nothing else than to recognize that one has a duty, ceteris paribus, ${ }^{84}$ to return it to him.

Most generally, this is the reason that Aquinas repeatedly offers that the first precepts of law must pertain to justice-which renders each his own. Aquinas frequently provides arguments ${ }^{85}$ that only cohere if the two meanings of debitum (debt and duty) are not distinct meanings but mutually implicative, such that debitum can be used interchangeably to indicate owing (as a debt) and ought (as a duty) without equivocation. Aquinas uses this rich notion of debitum to move immediately from what is owed to someone to what is a moral duty enjoined by law. For example, "the precepts of the decalogue are placed in the Law, as first principles, which need to be known to all from the outset. Wherefore the precepts of the decalogue had to be chiefly about those acts of justice in which the notion of duty [debiti] is manifest." ${ }^{\prime 6}$ The notion of debitum as due treated

84 To any who might object to the inclusion of ceteris paribus, I would note that the whole point of this article (ST I-II, q. 94, a. 4) is precisely to point out that such ceteris paribus clauses attach to all but to most general moral norms.

85 ST I-II, q. 100, a. 3, ad 3; q. 100, a. 5, ad 1; II-II, q. 140, a. 1, ad 3; q. 56, a. 2, corp.; II-II, q. 122, a. 1, corp. See also the following notes.

86 ST II-II, q. 140, a. 1, ad 3. 
by justice is identical to the notion of debitum as duty expressed by law. Again, "justice, more than any other virtue, regards its object under the aspect of something due [rationem debiti], which is a necessary condition for a precept." 87 The notion of "due" that justice treats is the same "due" that is essential to the ratio of precept (i.e., duty or obligation). And again, he writes: "Justice alone, of all the virtues, implies the notion of duty [rationem debiti]. Consequently moral matters are determinable by law in so far as they belong to justice" 88

Thus I believe Finnis touches but dismisses the solution to the is-ought problem in his treatment of Hugo Grotius: "Translators of [Grotius] . . . often render debiti as 'obligatory.' But this fails to preserve the delicate ambiguity in the thought of Grotius and his sources." ${ }^{89}$ As I have pointed out, this equation of "due" and "duty" is not an ambiguity (at least, not in Aquinas); rather, the equivalence of the "two" meanings of debitum is crucial to his theory of law.

Finnis continues: "Granted that we can discern right and wrong, due and undue, by reasoning, what makes it obligatory to choose the right and due and to avoid the wrong and undue?" I answer: simply that one who fails to see that he (morally) ought to render what he owes to another has not actually understood what it is to owe something to someone. Owing something to another is, for Aquinas, precisely what it is to be obligated. Once I have judged that I really do owe something to someone, then it becomes unreasonable, "repugnant to right reason," ${ }^{\circ 0}$ for me to choose to withhold what I owe. To be categorically demanded by reason is all it is for a thing to be obligatory, and to be an absolute condition of acting in accord with right reason is all that is required to impose the hypothetical necessity proper to obligation on the will. That English has severed the etymological connections between "owes" and "ought" and between "due" and "duty" is, from Aquinas's perspective, an unfortunate corruption.

And we can go a step further. If obligation is entailed by such bridge concepts, factual descriptors of relations that entail owing, then we can

87 ST II-II, q. 56, a. 1, ad 1; cf. a. 2, corp.

88 ST I-II, q. 99, a. 5, ad 1. This must be read in the context of the corpus, where Aquinas writes, "The things that have to be done do not come under the precept except in so far as they have the character of a duty [debiti rationem]"). One may wonder how this claim - that the notion of due is essential to law and obligationis to be reconciled with the earlier example of vowing. In answer, note that a vow is always made to someone, such that to vow is to place oneself in a relation of owing something to another.

89 Finnis, Natural Law and Natural Rights, 44.

$90 \quad$ ST I-II, q. 18, a. 5, ad 4; aa. 8-10. 
see why Aquinas seems to identify synderesis, whereby we apprehend first moral principles (specifically, first moral norms), with the speculative habit of understanding. I see no reason to think that understanding the very notion of vowing or the very concept of ownership, or even the notion of owing, is not a task of the speculative intellect.

Indeed, Aquinas holds that not only speculative principles but also practical (and evidently moral) principles, such as "one should do evil to no man," belong to the "understanding which is an intellectual virtue." 1 And in a parallel passage, he says that man takes the universal principles of action from "the understanding of principles, whereby he understands that he should do no evil." (Again, the habit of understanding is a habit of the speculative intellect. $)^{93}$ Similarly, he justifies calling conscience "the law of understanding" by appeal to its relation to synderesis, ${ }^{94}$ and he says the judgment of conscience consists in pura cognitione and that it is made by speculando per principia. ${ }^{95}$ And of the supernatural gift of understanding (which perfects the natural, speculative habit of understanding), he says, "the gift of understanding extends also to certain actions, not as though these were its principal object, but in so far as the rule of our actions is the eternal law, to which the higher reason, which is perfected by the gift of understanding, adheres by contemplating and consulting it." ${ }^{96}$ In short, I believe that synderesis and understanding are, if not strictly the same habit, at least distinguished by an all but inconsequential difference. That is, it seems to me that understanding takes on the label "synderesis" and becomes "practical" when it considers notions (like owing, debitum, justice, owning, or vowing) that immediately bear implications about what is reasonable or unreasonable action. ${ }^{97}$ It is through the understanding of such concepts that synderesis discovers moral law.

I am free to suggest that "ought" arises in the speculative intellect in this way because I have maintained the distinction between "ought" and "wants." If we expect obligation, of itself, to move the will, then one cannot root our apprehension of obligation in speculative knowledge. As we noted at the outset, speculative knowledge alone does not give rise to value and cannot move one to act; but if obligation and value are distinct, the fact-

ST II-II, q. 49, a. 2 , ad 1.

$S T$ I-II, q. 58, a. 5, corp.

See ST I-II, q. 57, a. 2, and In VI eth., lec. 5, no. 4.

De veritate, q. 17 , a. 2 , ad 4.

De veritate, q. 17 , a. 1 , ad 4.

$S T$ II-II, q. 8, a. 3; see also a. 6.

97 See for example, Yves Simon, A Critique of Moral Knowledge, trans. Ralph McInerny (New York: Fordham University Press, 2002), 5-7. 
value gap poses no problem to deriving obligations. An obligation provides the intellect with a reason to perform some act, but it does not necessarily and immediately move the will. Whether I owe something to another and whether it is good for me to give it to him are two different questions. Determining that it would be unreasonable of me not to do something is not precisely the same as recognizing that doing that thing satisfies some appetite that I experience. That I am conscious of having made a vow does not imply that I want to keep it or that I somehow see that it is advantageous to keep it or that I understand that it is perfective of me to keep it. What it does imply is that it would be, ceteris paribus, positively unreasonable of me to refuse to fulfill it, and that is all that is needed for me to find myself obliged to fulfill it.

Nonetheless, doing what is reasonable always does answer to one of our natural inclinations. Speculative knowledge can move us to act, because humans $d o$, by nature, experience a desire to live according to reason: "Since the rational soul is the proper form of man, there is in every man a natural inclination to act according to reason: and this is to act according to virtue. Consequently, considered thus, all acts of virtue are prescribed by the natural law: since each one's reason naturally dictates to him to act virtuously." ${ }^{\text {8 }}$ Man, as rational, has a natural inclination to act according to reason, and that is nothing else than to act according to virtue. So fulfilling obligation will always answer to at least one experienced desire, a preeminent desire that should, but does not necessarily, trump other desires. But again, the order is crucial: I first apprehend what is obligatory as obligatory, and, in light of that apprehension, I then also apprehend it as desirable. Indeed, it is only because I have already judged that it is absolutely to be done that I can subsequently grasp that it is of itself always good for me in being uniquely reasonable.

Because our apprehension of obligation as such does not directly include the notion of what is perfective of us, this account does not jeopardize the universality of the natural law. ${ }^{99}$ The sort of speculative knowledge wherein I root the apprehension of obligation is quite plausibly universalthe concept of, for example, ownership is quite common. No knowledge of philosophical anthropology—let alone of natural theology—is required. ${ }^{100}$

98 ST I-II, q. 94, a. 3, corp.

99 See for example, Finnis, Natural Law and Natural Rights, 48 and 77, where he sketches the problem.

100 I find myself in agreement with both Veatch ("Natural Law," 258) and Finnis ("Natural Law and the 'Is'-'Ought' Question: An Invitation to Professor Veatch," Catholic Lawyer 26 [1981]: 266-77, at 270). Veatch observes: "It is no less impos- 
There is, then, no danger that only philosophers can have accurate knowledge of the first precepts of the natural law.

What of the logical problem that nothing can be in the conclusion that was not in its premises? This is not violated by what I am suggesting. The logical autonomy of ethics is maintained, because any syllogistic reasoning about what is right and obligatory starts with per se nota propositions that already include moral predicates. What is shared between the speculative and practical intellects in discovering obligations is only an apprehension of a concept or ratio, like the concept of vowing or the concept of property. It is prior to any syllogism-indeed, prior to any proposition-so the logical rules about what sort of conclusions can be drawn from which sorts of premises do not yet apply. In the first place we grasp general notions (like ownership or vowing), which, in turn, imply general, per se nota norms that can be viewed as conditional in structure, such as that, if someone owns something, then (all else being equal) I ought not interfere with his use of it; said otherwise, I owe it to him not to deprive him of that property. Such a norm is a bridge principle: the protasis (that someone owns something) is a question of fact, while the apostasis (that I ought not interfere with his use of it) is normative. ${ }^{101}$ Then, conscience can judge whether the descriptive protasis of this general norm is, as a matter of fact, fulfilled in this or that case and draw a normative conclusion: this person does own this thing, therefore I ought not deprive him of its use. ${ }^{102}$

sible to determine, or even to adequately state what a human being is without making reference to what he ought to be or to that natural end, fulfillment or good, which it is incumbent upon any human being, by nature, to try to be or become," although as Finnis presses, "does not his view that a full knowledge of human nature involves a knowledge of what is 'incumbent upon' human beings suggest that, epistemologically, a knowledge of what is good for human beings, and thus incumbent upon them, is a condition precedent to any full knowledge of human nature[?]" Moral experience (including experience of obligation) is an important datum that precedes any adequate anthropology, not vice versa, in the same way that moral experience must be a given that is better known to us that God's existence, if a moral proof of God is to be intelligible.

101 This conditional structure is important. I can apprehend the norm prior to knowing the particular cases in which it applies or even whether there are any such cases. Thus, an agnostic or even an atheist can know the general moral norm that if there is a personal God of the sort that classical theists confess, then he owes obedience to that God.

102 We ought, I think, distinguish two similar but distinct rational processes that we might be tempted to call "conscience." One-which I identify with conscience properly so-called-applies the universal norms of synderesis here and now, determining that this act is or is not reasonable and must or must not be done. The other-which I reckon a work of prudence-takes the cultivation of virtue as an 
The logical law is preserved because, by the time we begin syllogistic reasoning, we already have an "ought" (or at least something that strictly implies an "ought") in the predicate. The transition from speculative to practical is prior to any proposition, so we are not moving from "is" to "ought." Rather, we are moving from a speculative apprehension of an abstract concept (like ownership or vowing) to a per se nota principle that has a descriptive subject and a predicate that stipulates conditions for rational behavior (or if we maintain its conditional structure, a factual protasis and a normative apodosis). It is those per se nota bridge principles that, in turn, allow us, in an incontrovertibly valid deduction, to derive an obligation from a judgment of fact. Thus I am not denying the logical autonomy of ethics; I deny only the semantic autonomy of ethics. ${ }^{103}$

What of Aquinas's repeated insistence that the will, as free, can only be subject to conditional or hypothetical necessity imposed by the desire for some end? This is not violated on my suggestion: what is right is by that fact categorically to be done in the judgment of the intellect, but the necessity that binds the will is only hypothetical: one must will to do what reason judges right only insofar as one desires to live according to reason. The will is not under an absolute necessity to obey conscience, because the natural desire to live according to reason is only one of many natural desires. As Aquinas notes, virtue is natural to us insofar as we have a natural desire to live reasonably, but we do not have a natural inclination to each act of virtue considered in its species. ${ }^{104}$

In sum, I suggest that we first apprehend (through the speculative habit of understanding) certain general notions that entail a relationship of owing something to someone. From such notions, we immediately grasp the truth of certain general, per se nota, moral norms (this step seems to me what Aquinas calls "synderesis," and this is the beginning of practical reason insofar as it guides appetite). We can then take account of various facts, determining that this norm applies here and now; that is, we judge that we are, in fact, in such a relationship that involves owing something to someone (this is the work of conscience), and therefore we can recognize

end intended by the agent and then determines how best to attain and guard that virtue. That the two are at least theoretically distinct can be seen in the kinds of judgments they reach: the first will reach absolute (categorical) judgments of what must or must not to be done, while the latter will make prudential (hypothetical) judgments which will often be counsels about how best and most surely to nurture virtue; see, e.g., ST I-II, q. 107, a. 2, and II-II, q. 184, a. 3.

103 For more on the distinction of the claims of logical and semantic autonomy, see Pigden, "Hume on Is and Ought."

104 ST I-II, q. 94, a. 3, corp. 
that it would be unreasonable of us not to render what it owed. In other words, conscience judges that we ought to give it to him, that we are bound by reason to give it to him. Whatever reason determines is, without qualification, to be done is then also perceived as good for the agent insofar as we have a natural inclination to live according to reason; what reason determines is categorically to be done necessarily corresponds to an experienced desire. This natural inclination to live according to reason makes it possible for us to will to do something for no other reason than that we believe it is right or reasonable. Thus, the will can will either to obey reason (following the judgment of conscience) or to follow one of our other natural inclinations in defiance of reason (which would constitute formal sin and introduce guilt). ${ }^{105}$ Once the will has willed either to follow or to defy reason, practical reason can arrange the means to the end willed (this is the work of prudence, the practical intellect that follows appetite for the end).

Hence Aquinas explains that prudence is ruled by a prior understanding of what is just and lawful, ${ }^{106}$ of what we owe to another. But prudence, which takes its principles from the appetites, can only be ruled in this way through that appetitive power which is the will. Our understanding of what is just (grasped by synderesis) guides prudence through the mediation of the rational appetite, which is the seat of the virtue of justice and which is responsive to reason's apprehension of what is due to another. ${ }^{107}$ $\mathrm{Sin}$ is thus, at root, the willful and selfish refusal to render the other what reason has judged is simply owed to the other, hence Aquinas's saying that legal justice is a general virtue and injustice is a general vice, in conformity with 1 John 3:4, "all sin is iniquity." 108

Of course, this process may fold over on itself so that these two functions of practical reason regularly end up more tightly intertwined in reality than my neat distinction might at first suggest. In actual deliberation, there is a constant interplay between the reason and will: the means we choose in order to obtain one end can themselves be taken as a more proximate end that we in turn deliberate about attaining. Further, the two functions of practical reason tend to overlap: at each step of arranging means to ends, conscience of moral norms can influence our prudential judgments because prudence can realize that some possible means of attaining one particular end would frustrate us by interfering with our attainment of

\footnotetext{
105 Described in De veritate, q. 17, a. 1, ad 4.

106 ST II-II, q. 57, a. 1, ad 2.

107 ST II-II, q. 58, a. 4, corp.

108 ST II-II, q. 58, a. 5, ad 3. Bear in mind that iniquitas is from in aequus, meaning literally, injustice or inequality.
} 
some other end that we also desire. ${ }^{109}$

Whether I am right to place our recognition of moral norms in the speculative apprehension of concepts that entail relations of owing is, however, not the principal point. ${ }^{110}$ What is essential to this discussion is that obligation and value are discrete concepts and that, in Aquinas's moral psychology, they are treated by different functions of practical reason: the practical reason that leads the appetite for the end (by appointing the end) and the practical reason that follows the appetite for the end (by arranging the means to the end). For this reason, obligation may be categorical to the intellect while being only hypothetical to the will. The fact of sin requires that value and obligation be distinct; it requires that what is decisive to the intellect not necessarily be decisive to the will. ${ }^{111}$ So long as we fail to distinguish obligation from value, so long as we fail to distinguish moral "ought" as perceived by the intellect from good as desired by the will, we will continue to face an insoluble problem. ${ }^{112}$

109 This alertness to various ends is diligence or solicitude, opposed by negligence; see ST II-II, q. 54, and q. 47, a. 9. Prudence takes account of the particular, but it is not myopic: it can attend to a number of disparate, desired goods even as it arranges the means to one particular good. I am hardly prudent if in my pursuit of one good I inadvertently destroy another that I hold dear.

110 The tentative nature of my account of synderesis's derivation of obligation from speculative understanding deserves to be stressed. I am suggesting a radical shift in our understanding of practical reason; many considerations have yet to be made, and much work-both textual and philosophical—remains to be done before we will be warranted in proposing detailed accounts with confidence. This must be left to a future work.

111 De veritate, q. 17, a. 1, ad 4.

112 I offer my thanks to R. J. Matava for his patient engagement with me on this project. 